\title{
new officers and councilors
}

\section{President}

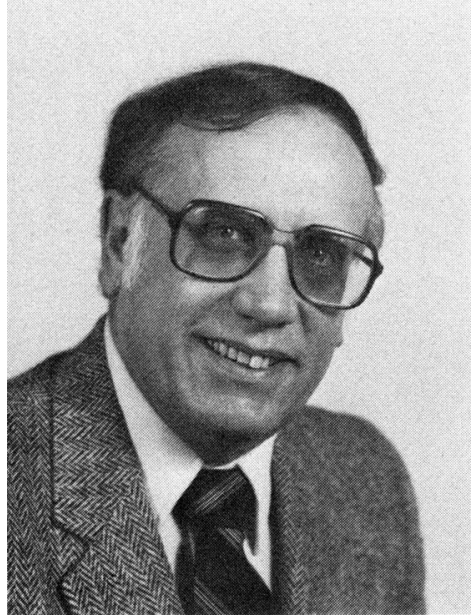

Richard E. Hallgren

\section{President-Elect}

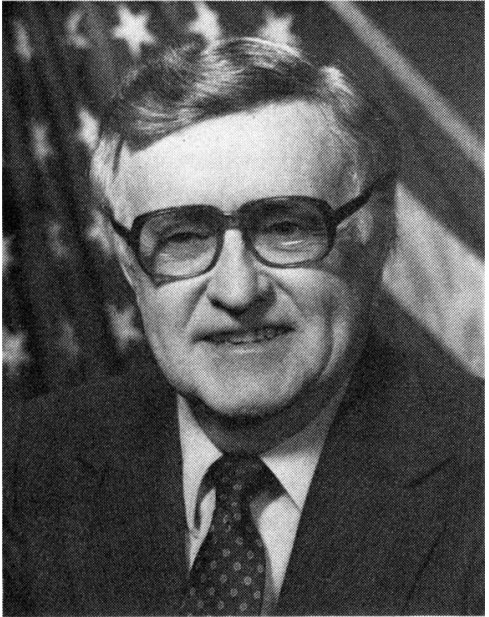

Earl G. Droessler

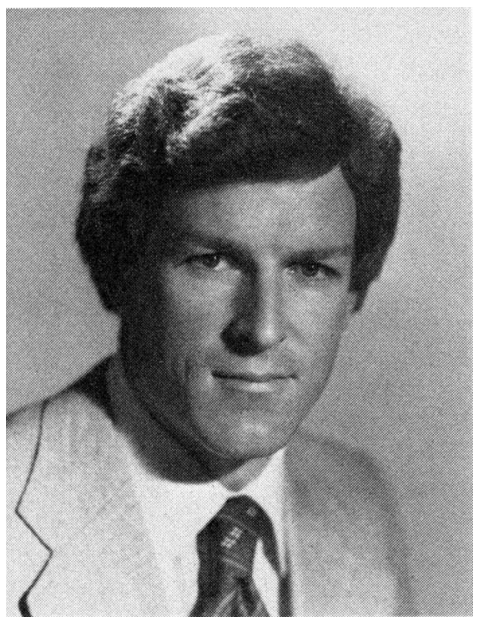

Robert T. Ryan

The President of the American Meteorological Society for 1982 is Dr. Richard E. Hallgren, Director of the National Weather Service (NWS), National Oceanic and Atmospheric Administration (NOAA), Silver Spring, Md. As President of AMS, he succeeds Dr. Robert G. Fleagle, Professor of Atmospheric Sciences at the University of Washington, Seattle, Wash

The results of the 1982 AMS election for the President-Elect and Councilors were announced on 11 January 1982 at the 62nd Annual Business Meeting of the Society in San Antonio, Tex.

The President-Elect who will assume office as President in 1983 is Dr. Earl G. Droessler, Director of University Affairs of NOAA, in Washington, D.C.

Each year, five Councilors are elected to three-year terms of office-four by the AMS membership, and one by the Council. Dr. William E. Gordon, Provost and Vice President of Rice University, Houston, Tex., was elected by the Council. Elected Councilors by the membership are: Dr. Neil L. Frank, Director of the National Hurricane Center of NOAA, Coral Gables, Fla.; Mr. Robert T. Ryan, Meteorologist for WRC-TV and WRC AM Radio, Washington, D.C.; Dr. Paul F. Twitchell, Visiting Professor at the U.S. Naval Academy, Annapolis, Md., on leave from the Office of Naval Research, Boston, Mass.; and Dr. Thomas H. Vonder Haar, Professor and Head of the Dept. of Atmospheric Sciences at Colorado State University, Ft. Collins, Colo.

\section{Councilors}

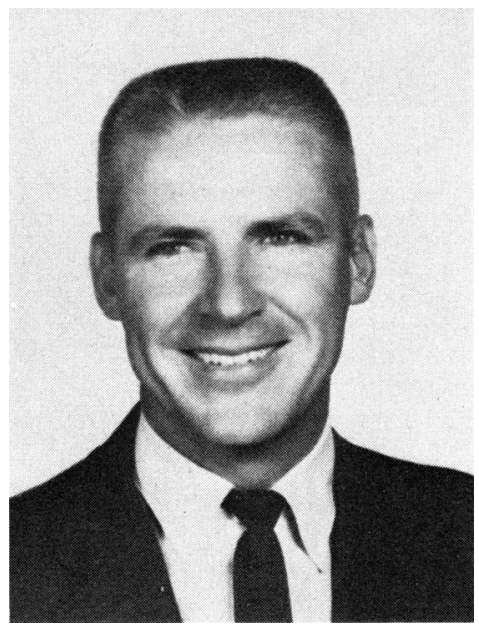

Neil L. Frank

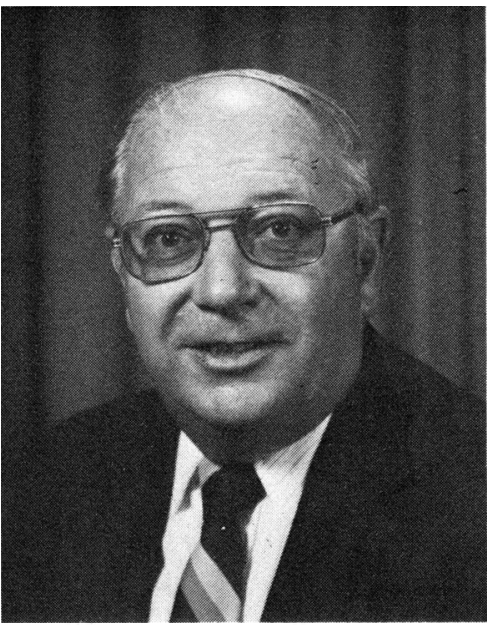

Paul F. Twitchell

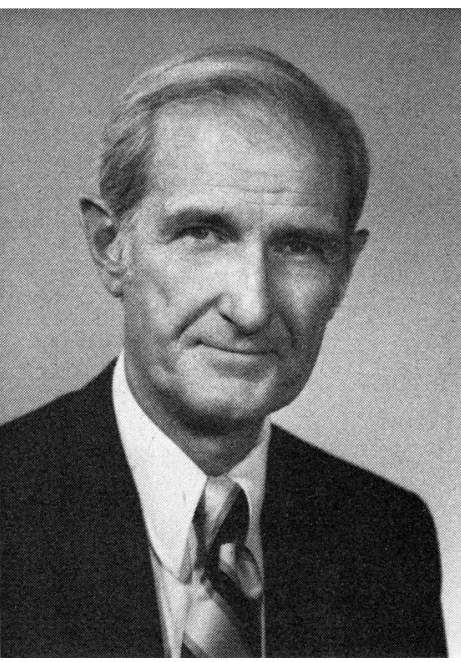

William E. Gordon

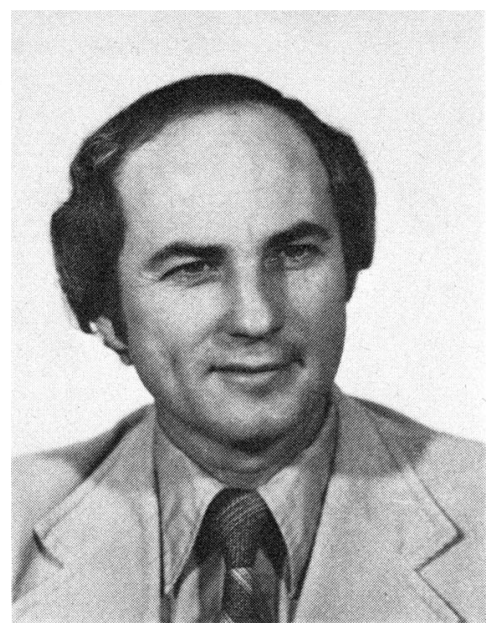

Thomas H. Vonder Haar 
President Richard E. Hallgren is the Director of NWS, a position he has held since 1979, and Acting Assistant Administrator for Oceanic and Atmospheric Services of NOAA. He is known internationally for his contributions to global weather programs, and as an innovator of concepts and systems designed to speed the acquisition, processing, and dissemination of weather information. Dr. Hallgren received both the B.S. (1953) and the Ph.D. (1960) from Pennsylvania State University at University Park. During 1954-1956, he served as a staff weather officer and operational weather forecaster in support of the Strategic Air Command, a division of the U.S. Air Force. In 1960, Dr. Hallgren joined the IBM Corporation as an Operations Research Analyst and was named Manager of the Meteorological Systems Department in 1962. He was appointed Scientific Advisor to the Assistant Secretary for Science and Technology of the U.S. Department of Commerce (DOC) in 1964. In 1966, he became the first Director of the Office of World Weather Systems of what was then the Environmental Science Services Administration (ESSA), which later became NOAA. Under ESSA, he also was Assistant Administrator for Environmental Systems. From 1971-1973, Dr. Hallgren served as Associate Administrator for Environmental Monitoring and Prediction of NOAA, and was twice Federal Coordinator for Meteorological Services and Supporting Research (19701971 and 1977-1979). Dr. Hallgren was appointed Deputy Director of NWS in 1973. Four years later, he became NOAA's Acting Assistant Administrator for Oceanic and Atmospheric Services, a position he held for two years, and assumed again in 1981 in addition to his directorship of NWS. Dr. Hallgren has been active on national and international panels and committees, including the Intergovernmental Oceanographic Commission (United Nations Educational, Scientific, and Cultural Organization (UNESCO)), Integrated Global Ocean Station System, Working Committee (U.S. member, 1971-1973), and the World Meteorological Organization (WMO) Tropical Experiment Board (U.S. member, 1971-1973). Over the years, he has taken an active part in the development of the World Weather Watch of WMO, which led directly to his participation in the planning for the Global Atmospheric Research Program (GARP) Atlantic Tropical Experiment (GATE) during the summer of 1975. In 1981, the Department of State appointed Dr. Hallgren as Permanent Representative of the United States to the WMO. As U.S. Representative, he coordinates this country's involvement in global meteorological programs. $\mathrm{He}$ is a member of the Executive Board of Directors of the American Oceanic Organization, and a member of Sigma $\mathrm{Xi}$. In 1968, he was the recipient of one of the Arthur S. Fleming Awards presented to outstanding young men in the Federal government, and in 1969 he received the DOC Gold Medal. He has published scientific and technical papers in the areas of meteorological systems, cloud physics, and atmospheric electricity, and made presentations at national and international conferences. An AMS Fellow since 1973, Dr. Hallgren has served the Society as a member of the Committee on Fellows and Honorary Members (1975) and as Chairman of both the AMS Pennsylvania State University Chapter (1951-1953) and the Washington, D.C., Chapter (1969-1970).
President-Elect Earl G. Droessler is the Director of University Affairs of NOAA, in Washington, D.C. Dr. Droessler holds the A.B. (1942) in mathematics from Loras College, Dubuque, Iowa. In 1944, he graduated from the Post Graduate School of the U.S. Naval Academy at Annapolis, Md., and received an honorary Sc.D. (1958) from Loras College. After military service as an aerological officer during the war, he became head of the Geophysics Branch of the Office of Naval Research. From 1950-1951, he was awarded a Fullbright Fellowship to study meteorology at the University of Oslo, Norway. In 1952, he was appointed Deputy Head of the Office of Research, Office of the Secretary of Defense, where he served until 1958. Dr. Droessler then was Program Director for Atmospheric Sciences and the Head of the Section on Atmospheric Sciences of the National Science Foundation (NSF) from 1958-1966. He spent 1963-1964 as a Visiting Research Fellow at the Radiophysics Laboratory of the Commonwealth Scientific and Industrial Research Organization in Sydney, Australia. From 1966 until 1971, Dr. Droessler was Professor of Atmospheric Sciences and Vice President for Research and Development at the State University of New York at Albany. He also served as the Vice President and Treasurer of the State University of New York at Albany Foundation, Inc. Dr. Droessler was appointed Professor of Geosciences and Dean for Research at the North Carolina State University at Raleigh in 1971, and was subsequently appointed Vice Provost. In 1979, he joined NOAA as Director of University Affairs. Dr. Droessler is a Fellow of the AMS, the American Geophysical Union, and the American Association for the Advancement of Science. He served on the Board of Trustees of the University Corporation for Atmospheric Research from 1969-1973, and was Chairman from 1971-1972. From 1975-1977, he was cochairman of the National Science Foundation Weather Modification Advisory Panel. Dr. Droessler has been an Executive Editor of Weatherwise since 1977, and co-edited with A. Blackadar The Future of National Atmospheric Research in 1977. He has served on a number of AMS committees, including the Awards Committee (1952-1954; Chairman, 1958-1960); Publications Commission (1954-1956); Councilor (1960-1962); Membership Commission (Chairman, 19641971); the Weather Modification Committee (Chairman, 1966-1971); and the Scientific and Technological Activities Commission (Chairman, 1974-1981). In 1976, Dr. Droessler was the recipient of the AMS Charles Franklin Brooks Award for Outstanding Service to the Society.

\section{Councilors}

Councilor Neil L. Frank is the Director of the National Hurricane Center of NOAA, Coral Gables, Fla. Dr. Frank holds the B.A. (1953) in chemistry from Southwestern College, Kansas, and the M.S. (1959) and Ph.D. (1970) in meteorology from Florida State University. From 1953-1957, he served as a Weather Officer in the U.S. Air Force, and then spent the next four years in graduate studies and research at Florida State University. Dr. Frank was the District Forecaster for the National Hurricane Center in Miami, Florida 
from 1961-1966, and was subsequently appointed Assistant Director, Tropical Analysis Center in Miami, a position he held until 1968. From 1968-1972, he was Hurricane Specialist for the National Hurricane Center, and was then promoted to Deputy Director. In 1974, he was appointed Director of the Center. Dr. Frank served in an advisory capacity as U.S. Consultant for a WMO seminar on tropical meteorology in 1964. He was Director of meteorological support for Project BOMEX (Barbados Oceanographic and Meteorological Experiment) in 1969, and from 1969-1970, he served as Consultant to the World Bank for drafting a cyclone warning plan for East Pakistan. Dr. Frank was a member of the GATE Advisory Panel to the U.S. GARP Committee, and was a member of the AMS Committee on Tropical Meteorology, 1973-1978; Chairman, 1975. In 1966, he was President of the AMS Miami Chapter, and has published in AMS and other scientific publications.

Councilor William E. Gordon is Provost and Vice President of Rice University, Houston, Tex. Dr. Gordon holds the B.A. (1939) in mathematics and the M.A. (1941) in educational administration from Montclair State College, New Jersey; the M.S. (1943) in meteorology from New York University; and the Ph.D. (1953) in electrical engineering from Cornell University. His graduate studies were interrupted by World War II, when he rose from private to captain in the Army Air Corps. After the war, he was Associate Director of the Electrical Engineering Research Laboratory of the University of Texas, before joining the research staff at Cornell, and subsequently earning his Ph.D. From 1953-1959, Dr. Gordon was Associate Professor at Cornell, where he was researching radiowave scattering in the atmosphere. He became a full professor in 1959. In 1960, he was appointed Director of Cornell's Arecibo Ionospheric Observatory in Puerto Rico. He was the principal designer, contractor and coordinator of the observatory, which he directed until 1966. Dr. Gordon was named Walter R. Read Professor of Engineering in 1965. In 1966, he was appointed Dean of Engineering and Science at Rice University, combining in one position the administrative responsibilities for both divisions of the university. In addition, he was named Professor of Electrical Engineering and Space Science. In 1975, he was appointed Dean of the School of Natural Sciences. He subsequently became Provost and Vice President of the university. Dr. Gordon has served as chairman of the U.S. National Committee of the International Scientific Radio Union (URSI), was Vice President and Treasurer (1975-1981), and is President of URSI (1981--). He was chairman of the Committee on Scientific Radio, National Academy of Sciences (1947-1960). In connection with Associated Universities, Inc., he has served on the Advisory Committee on Radio Astronomy of the National Radio Astronomy Observatory. Dr. Gordon has served on the NSF Panel on Atmospheric Science (1967-1974) and the National Academy of Science's Commission on Solar Terrestrial Research (1966-1974). He was a member of the Research Advisory Committee of the NSF from 19731976, and since 1977 he has served on the Advisory Board of the Arecibo Ionospheric Observatory. In 1971, and again from 1973-1978, Dr. Gordon was Chairman of the Board of
Trustees of the Upper Atmospheric Research Corporation. Since 1979, he has been Chairman of the University Corporation for Atmospheric Research. His other national and international scientific assignments have been numerous. He is a Fellow of the Institute of Electrical and Electronics Engineers and has been an AMS member since 1945. Dr. Gordon is a member of many other scientific and honorary societies, including the National Academy of Sciences and the National Academy of Engineering.

Councilor Robert T. Ryan is a Meteorologist for NBC's WRC-TV and WRC AM Radio in Washington, D.C. Mr. Ryan holds the B.S. (1968) from the State University of New York at Binghamton, and the M.S. (1973) in atmospheric sciences from the State University of New York at Albany. From 1968-1974, he was a Research Meteorologist with Arthur D. Little, Inc., in Cambridge, Mass. He was also Principal Meteorologist for WKGB-TV in Boston (1969-1970), WPRI-TV in Providence, R.I. (1971-1972), and WCVB-TV in Boston (1972-1978). From 1978-1980, Mr. Ryan was Meteorologist for NBC's TODAY Show in New York City. He has been a Meteorologist with WRC-TV and Radio since 1980. Mr. Ryan was granted the AMS Seal of Approval for Television in 1971. He has been a member of the Society's Board of Broadcast Meteorology since 1978, and has served as Chairman since 1981. Mr. Ryan has published several articles in the Society's publications, and has presented papers at AMS conferences on weather modification, severe local storms, and radio-TV weathercasting.

Councilor Paul F. Twitchell is a Visiting Professor at the U.S. Naval Academy, Annapolis, Md., on leave from the Office of Naval Research, Eastern/Central Regional Office, Boston, Mass. Dr. Twitchell holds the B.S. (1953) in physics from Boston College; the B.S. (1954) in meteorology from Pennsylvania State University; the M.S. (1962) in geophysics from Boston College; and the Ph.D. (1976) from the University of Wisconsin-Madison. From 1954-1957, Dr. Twitchell was a Weather Officer for the U.S. Air Force Weather Central in Washington, D.C., and has remained in the U.S. Air Force Reserve, advancing to the rank of Colonel. In 1961, he joined Melpar Inc. in Boston, Mass. as a Research Engineer, and was promoted to Senior Research Engineer in 1962 . He then joined the Office of Naval Research as a meteorologist. From 1964-1965, Dr. Twitchell was Acting Scientific Liaison Officer at Woods Hole Oceanographic Institution in Woods Hole, Mass. He spent the years from 1969-1971 as a Visiting Investigator for the New England Aquarium. Dr. Twitchell is a member of Sigma Xi and was the recipient of the U.S. Air Force Spengler Award in 1976. He has served on a number of AMS committees, including the Admissions Committee (1962-1964, 1967-1969, 1976-1980; Chairman, 1979-1980); the Committee on the Interaction of Sea and Atmosphere (1970-1977; Chairman, 1970-1971, 1975-1976); and the Committee on Meteorology of the Coastal Zone (1979-present). Dr. Twitchell held several offices in the AMS Greater Boston 
Chapter, including that of Chairman (1968-1969). He has published articles in publications of the AMS, the American Geophysical Union, and the Institute of Electrical and Electronics Engineers, and has presented lectures and papers at international conferences and symposia.

Councilor Thomas H. Vonder Haar is Professor and Head of the Department of Atmospheric Sciences at Colorado State University (CSU), Ft. Collins, Colo. Dr. Vonder Haar holds the B.S. (1963) in meteorology from Parks College of St. Louis, Mo., and the M.S. (1964) and the Ph.D. (1968) in meteorology from the University of Wisconsin at Madison (UW-M). He has been associated with UW-M as a Research Assistant (1963-1965); Research Project Supervisor (19651967); Assistant Scientist, Space Science and Engineering Center (1968-1969); and Associate Scientist (1969). He joined the CSU faculty in 1970 as an Assistant Professor and was named Associate Professor in 1972. He became Head of the Department of Atmospheric Sciences in 1974, and a full Professor in 1978. Dr. Vonder Haar has participated in many invited academic seminars and has served as principal or coinvestigator on federal contracts and grants. He has been a research consultant for governmental and scientific organizations; and has participated in numerous committees and activities of CSU and the surrounding community. He has been an active participant in many national and interna- tional planning and advisory groups, including the Panel on Remote Sensing, the Committee on Space Research, Working Group 6, Meteorology and Earth Resources; several GATE working groups; two U.S. delegations of U.S.-U.S.S.R. Panels of Experts dealing with climate; the WMO Working Group on Aerosol Dynamics; the U.S. Atmospheric Radiation Working Group (ad hoc); the Science Steering Group for the National Aeronautics and Space Administration (NASA) Climate Program; the Science and Analysis Team for the Earth Radiation Budget Experiment on the Nimbus-G satellite; and the International Radiation Commission, International Association for Meteorology and Atmospheric Physics of the International Union of Geodesy and Geophysics. He also has been on various committees of the University Corporation for Atmospheric Research and the National Academy of Sciences. Dr. Vonder Haar has presented more than 60 papers at national and international science meetings and is author or coauthor of more than 115 scientific articles. Some of his original research now is being included in textbooks and summaries of atmospheric science and atmospheric physics by authors both in the United States and abroad. He is an Associate Editor of both the Journal of Geophysical Research and the AMS Journal of Applied Meteorology. He has been active within the Society, serving on the Committee on Radiation Energy (1970-1977; Chairman, 1972-1974) and on the Awards Committee (1976). In 1981, Dr. Vonder Haar was the recipient of the Society's Second Half Century Award.

\title{
Preprints
}

\section{Conference on Atmospheric Environment of Aerospace Systems and Applied Meteorology}

\author{
November 14-16, 1978 New York, N.Y.
}

The Conference on Atmospheric Environment of Aerospace

Systems and Applied Meteorology, sponsored by the

American Meteorological Society with the cooperation

of the American Institute of Aeronautics and

Astronautics, was held 14-16 November 1978 in New

York, N.Y. This volume contains over 35 papers

grouped under the following session topics:

Space vehicle-environmental interactions •

Recent developments in aeronautical

meteorology - Satellite sensor and data

processing improvements - Satellite

products and applications *

verse weather analysis and

modeling • Ad-

vances in

automation

of

meteoro-

logical

data and

services

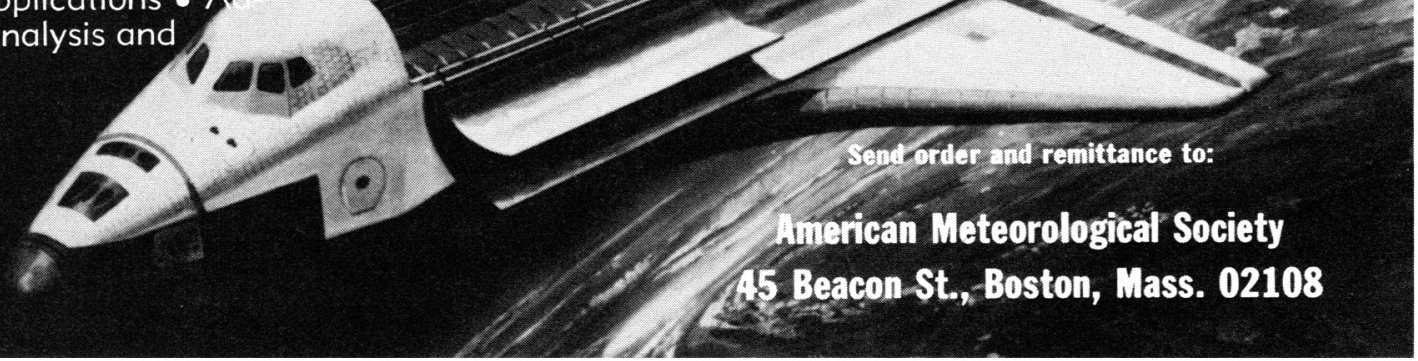

